227 PREVALENCE OF NPSLE IN NORTH-INDIAN SLE PATIENTS AND ITS IMPACT ON QUALITY OF LIFE

${ }^{1} \mathrm{H}$ Muhammed*, ${ }^{2} \mathrm{~V}$ Lal, ${ }^{1} \mathrm{~V}$ Dhir, ${ }^{2} \mathrm{MK}$ Goyal. ${ }^{1} P G I M E R$, Internal Medicine, chandigarh, India; ${ }^{2} P G I M E R$, Neurology, chandigarh, India

\subsection{6/lupus-2017-000215.227}

Background and aims To look at the prevalence of neuropsychiatric manifestations in patients with SLE and assess its impact on qol
Methods We included consecutive patients with SLE above the age of 18 [(SLICC) 2012]. A diagnosis of an NP (neuropsychiatric) syndrome was made as per ACR 1999 definitions. Manifestations occurring at any point of time after the diagnosis of SLE were considered. Some modifications used were - headaches were included if $>4$ hours, mood disorders or anxiety was considered if the patient reported them to cause 'significant distress or impairment in functioning'. Cognitive testing was done by using the mini-mental state examination (cut-off of 23). Testing for autonomic neuropathy only involved blood pressure response to standing $(>=30 / 15$

Abstract 227 Table 1 Comparison of basic descriptors among patients with and without NPSLE

\begin{tabular}{|c|c|c|c|c|}
\hline & $\begin{array}{l}\text { All SLE patients } \\
\mathrm{n}=101\end{array}$ & $\begin{array}{l}\text { Patients with } \\
\text { NPSLE } \\
\mathrm{n}=33\end{array}$ & $\begin{array}{l}\text { Patients } \\
\text { without NPSLE } \\
\mathrm{n}=68\end{array}$ & $p$ value \\
\hline Age, years $\pm S D$ & $32.3 \pm 10.0$ & $31.9 \pm 9.9$ & $32.5 \pm 10.2$ & 0.780 \\
\hline $\begin{array}{l}\text { Duration, } \\
\text { years } \pm S D\end{array}$ & $4.6 \pm 4.5$ & $4.5 \pm 4.1$ & $4.7 \pm 4.8$ & 0.837 \\
\hline $\begin{array}{ll}\text { Age } & \text { at } \\
\text { diagnosis, } & \\
\text { years } \pm S D & \end{array}$ & $27.8 \pm 9.1$ & $27.5 \pm 8.7$ & $27.9 \pm 9.4$ & 0.837 \\
\hline Sex ratio $(\mathrm{M} / \mathrm{F})$ & $9 / 92$ & $1 / 32$ & $8 / 60$ & 0.148 \\
\hline $\begin{array}{l}\text { Serum } \\
\text { creatinine, } \\
\mathrm{mg} / \mathrm{dl} \pm \mathrm{SD}\end{array}$ & $1.23 \pm 0.71$ & $1.3 \pm 0.9$ & $1.2 \pm 0.6$ & 0.509 \\
\hline SLEDAI, \pm SD & $24.23 \pm 12.9$ & $31.1 \pm 15.5$ & $20.9 \pm 9.9$ & 0.001 \\
\hline $\begin{array}{l}\text { Hematological- } \\
\text { no(\%) }\end{array}$ & $81(80.2)$ & $24(72.7)$ & $57(83.8)$ & 0.189 \\
\hline $\begin{array}{l}\text { Malar rash- } \\
\text { no(\%) }\end{array}$ & $38(37.6)$ & $10(30.3)$ & $28(41.2)$ & 0.290 \\
\hline $\begin{array}{l}\text { Oral ulcer - } \\
\text { no(\%) }\end{array}$ & $36(35.6)$ & $12(36.3)$ & $24(35.2)$ & 0.925 \\
\hline $\begin{array}{l}\text { Nephritis } \\
\text { no }(\%)\end{array}$ & $57(56.4)$ & $15(45.5)$ & $42(61.8)$ & 0.121 \\
\hline ILD- no(\%) & $4(4.0)$ & $1(3.0)$ & $3(4.4)$ & 0.738 \\
\hline Carditis-no(\%) & $10(9.9)$ & $5(15.2)$ & $5(7.4)$ & 0.218 \\
\hline $\begin{array}{l}\text { Serositis- } \\
\text { no(\%) }\end{array}$ & $7(6.9)$ & $3(9.1)$ & $4(5.9)$ & 0.552 \\
\hline
\end{tabular}




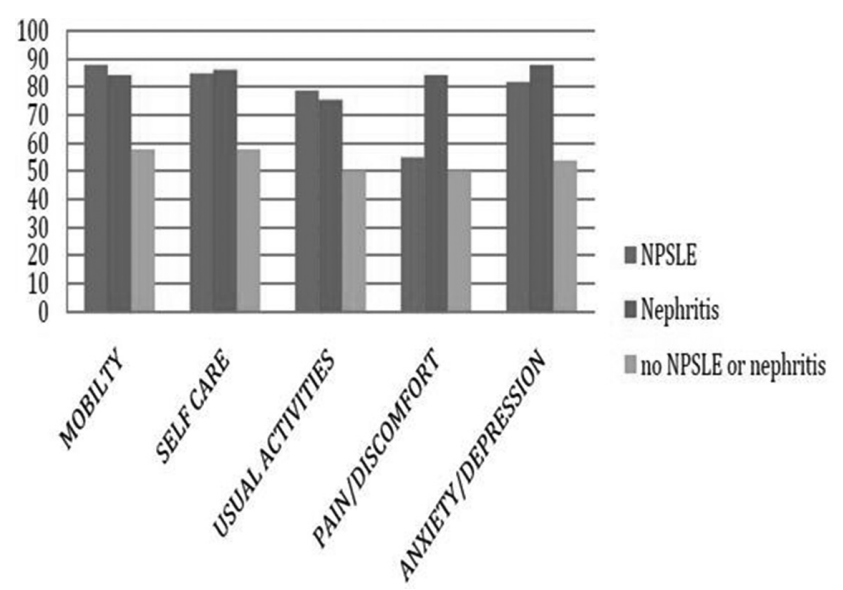

Abstract 227 Figure 1 Percentage of patients reporting problem in each

\begin{tabular}{|c|c|c|c|}
\hline \multirow{2}{*}{$\begin{array}{l}\text { Abstract } 227 \text { Table } 2 \\
\text { manifestations }\end{array}$} & \multicolumn{3}{|c|}{ Prevelance of Neuropsychiatric } \\
\hline & & $\begin{array}{l}\text { No. of } \\
\text { patients }\end{array}$ & $\begin{array}{l}\text { Percentage of } \\
\text { total SLE } \\
\text { patients } \\
00\end{array}$ \\
\hline \multirow[t]{7}{*}{ Central Nervous system } & $\begin{array}{l}\text { Headache } \\
\text { Seizure }\end{array}$ & $\begin{array}{l}10 \\
4\end{array}$ & $\begin{array}{l}9.9 \\
3.9\end{array}$ \\
\hline & Acute confusional state & 2 & 2.0 \\
\hline & Anviety disorder & 5 & 4.9 \\
\hline & Cognitive dysfunction & 4 & 3.9 \\
\hline & Movement disorder & 1 & 1 \\
\hline & Psychosis & 0 & 0 \\
\hline & Depression & 4 & 3.9 \\
\hline \multirow[t]{4}{*}{ Peripheral Nervous System } & Autonomic disorder & 2 & 1.9 \\
\hline & Cranial neuropathy & 0 & 0 \\
\hline & Mononeuritis multiplex & 1 & 1 \\
\hline & Polyneuropathy & 9 & 8.9 \\
\hline
\end{tabular}

abnormal). Screening for neuropathy was done in only $1 / 4$ patients by NCS. Quality of life was assessed by EURO QOL $5 \mathrm{D}$ questionnaire

Results This study included 101 patients of SLE. Among these, 33 patients had neuropsychiatric manifestations with a total of 42 events. The most common manifestation was headache (10) followed by anxiety disorder (5) and peripheral neuropathy (9). Other NPSLE syndromes observed in the study are seizure (4), cognitive dysfunction (4), depression (4), acute confusional state (2), autonomic disorder (2), movement disorder (1) and multiple mononeuropathy (1). Mann-whitney U test showed that there was statistically significant differences in self-care score $(p=0.002)$, limitation of mobility score $(\mathrm{p}=0.001)$, pain $\operatorname{score}(\mathrm{p}=0.005)$ between NPSLE vs no NPSLE.

Conclusions NP manifestations are common and lead to significant reduction in qol in North Indian SLE patients.

\section{MASSIVE PAINLESS ASCITES A RARE FORM OF ONSET OF SYSTEMIC LUPUS ERYTHEMATOSUS : A CASE REPORT}

E Musdalita*, M Sylvawani. Syiah Kuala University, Rheumatology division of Internal Medicine Departement, Banda Aceh, Indonesia

\subsection{6/lupus-2017-000215.228}

Background and aims Systemic lupus erythematosus (SLE) is an autoimmune disease characterised by involment of various organs. Serositis is commonly seen in SLE, approximately $16 \%$ of patients with SLE have pleural or pericardial involvement. However, peritoneal involment is extremely rare, and SLE with ascites as the first manifestation is an even rarer condition.

Methods A 36 - year old woman, a housewife was admitted with progressive painless abdominal distention for a month followd by early satiety and post prandial abdominal discomfort. There was no history of medication use, abdominal surgery, trauma or infection. The physical examination finding massive ascites without evidence of organomegaly or clinical stigmata of liver disease. Laboratory data were as follows : Haemoglobin 6,8 g/dl, BUN was normal and serum albumin $2,5 \mathrm{~g} / \mathrm{dl}$. Urinalysis evidenced erythrocytes $25 / \mathrm{ul}$ and proteinuria ++ . Puncture of ascitic fluid showed SAAG 1,1, total leukocyte count of 370 (PMN 10\%,MN 90\%), There is no bacterial growth and negative smear for malignancy. CT Abdomen revealed massive pelviabdominal free ascites

Results Patient diagnosed as lupus peritonitis treated with methylprednisolone and cyclosporin with substantial improvement of her condition.

Conclusions Lupus peritonitis as the initial SLE manifestation is rare, we described a case of SLE who presented with persistent massive unexplained ascites with good response to immunosuppressive therapy.

\section{MYCOPHENOLATE MOFETIL FOR INDUCTION OF REMISSION IN LUPUS ENTERITIS}

N Nasir*, A Syed, MM Riaz. Aga Khan University, Section of Internal Medicine- Department of Medicine, Karachi, Pakistan

\subsection{6/lupus-2017-000215.229}

Background and aims Lupus enteritis (LE) is a distinct gastrointestinal manifestation of systemic lupus erythematosus, and is a major cause of acute abdominal pain in these patients. Once recognised, management of this condition consists of immunosuppressive therapy with corticosteroids and other medications which includes cyclophosphamide, azathioprine and mycophenolate mofetil. Mycophenolate mofetil (MMF) is an immunosuppressive agent that inhibits both $\mathrm{B}$ and $\mathrm{T}$ lymphocyte proliferation. MMF reduces antibody production, and can affect glycosylation of adhesion molecules, and their in vitro expression.The aim of study was to determine the efficacy of Mycophenolate mofetil in the induction of remission in patients with lupus enteritis.

Methods We describe a case series of five patients with lupus enteritis. Laboratory features included low complement levels , anaemia, leukocytopenia or leukocytosis and thrombocytopenia .Median CRP level was $2.0 \mathrm{mg} / \mathrm{dL}$ (range 0-8.2 mg/dL) Acute kidney injury was present in $60 \%$ of the cases. Ct abdomen revealed bowel wall oedema (95\%), ascites (92\%), the characteristic "target sign" (98\%), mesenteric abnormalities (88\%) 